\title{
Energy Analysis of the Educational Building in Palembang Indonesia
}

\author{
Heni Fitriani", Muhammadiya Rifki, Citra Indriyati, Aditya Rachmadi, Ahmad Muhtarom \\ Department of Civil Engineering, Universitas Sriwijaya, Indonesia
}

Received February 11, 2021; Revised April 12, 2021; Accepted April 23, 2021

\section{Cite This Paper in the following Citation Styles}

(a): [1] Heni Fitriani, Muhammadiya Rifki, Citra Indriyati, Aditya Rachmadi, Ahmad Muhtarom, "Energy Analysis of the Educational Building in Palembang Indonesia," Civil Engineering and Architecture, Vol. 9, No. 3, pp. 778-788, 2021. DOI: 10.13189/cea.2021.090319.

(b): Heni Fitriani, Muhammadiya Rifki, Citra Indriyati, Aditya Rachmadi, Ahmad Muhtarom (2021). Energy Analysis of the Educational Building in Palembang Indonesia. Civil Engineering and Architecture, 9(3), 778-788. DOI: 10.13189/cea.2021.090319.

Copyright $(2021$ by authors, all rights reserved. Authors agree that this article remains permanently open access under the terms of the Creative Commons Attribution License 4.0 International License

\begin{abstract}
The issues of global warming and the greenhouse effect are of enormous concern today for most people. With increased demand for energy and a reduction in existing energy resources, demands for more energy efficient buildings within the construction industry are growing rapidly. Buildings are one of the largest energy consumers and account for about $40 \%$ of total energy consumption. This study aims to investigate the energy consumption of existing building located in Palembang as compared to the benchmark of Indonesian Standard for educational buildings. This paper also develops an energy analysis model with BIM integration to produce accurate predictions of the educational building performance with better scenarios. The EUI calculations were carried out in two ways. First, the electrical usage used in the building was calculated and then compared with the SNI 03-6196-2000 standard. Secondly, a 3D model was developed by redrawing the building object using BIM Revit application which follows the ASHRAE 90.1 benchmark standards. It was found that HVAC dominated for about $69 \%$ of the total energy consumption for the first floor, whereas electronic appliances contributed to the highest proportion of energy consumption, which was about $66 \%$, for the second floor. The EUI value for the first floor was $22.43 \mathrm{kWh} / \mathrm{m}^{2} /$ month, while the second floor was about $45.56 \mathrm{kWh} / \mathrm{m}^{2} /$ month, resulting in an average EUI of around $33.99 \mathrm{kWh} / \mathrm{m}^{2} /$ month. The existing building was then classified as a very inefficient building in terms of energy consumptions. Based on the renovation designs, 9 scenarios were then developed to measure potential energy
\end{abstract}

savings generated by the building using the Insight 360 web-based energy analysis tool. In the last scenario, considering a building installed with solar panels with a time limit of 30 years, $90 \%$ of surface coverage resulted in an EUI value of $-6.49 \mathrm{kWh} / \mathrm{m}^{2} /$ year with $102.10 \%$ of energy efficiency. This building scenario could provide energy export and save the energy excess. It can also be concluded that there was a significant improvement on energy use reduction and a substantial increase in energy savings under different renovation design scenarios. Finally, the results will help the decision makers identify the potential for energy savings in all energy-consuming facilities and equipment in the building as well as develop strategies for energy conservation.

Keywords Global Warming, BIM, Energy Analysis, Building Performance, EUI, HVAC

\section{Background}

The issue of sustainability and energy conservation has become an important topic in today's world community. With an increasing demand for energy consumption, demands for more energy efficient buildings within the construction industry are growing rapidly. Buildings are one of the largest energy consumers and account for about $40 \%$ of total energy consumption [1]. According to the Green Building Guidelines [2] in the Jakarta green building 
standards, most buildings in Indonesia normally use the HVAC (Heating, Ventilation and Air Conditioning) system and contribute to $47 \%-65 \%$ of the total building energy consumption.

The analysis of energy performance in buildings is important to discuss because of the demands for energy savings and their impacts on the environment. Several studies have been conducted to optimize the use of building energy, including the use of energy efficient technology and recommending various strategies in energy conservation [2-5]. Bergin et al [6] used BIM as a digital method and process for building performance analysis. Solla et al [7] examined the various possibilities for integrating BIM into green building performance assessment tools. A study by Fitriani [8] evaluated the efficiency of electrical energy in hospital buildings using the Ecotect software. Energy analysis is still mostly carried out only with statistical estimates or using simple static calculations. For this reason, it is necessary to develop an energy analysis for buildings using dynamic energy simulation software in order to predict energy consumption more accurately.

Building energy analysis must meet cost and project schedule requirements. According to Azhar et al [9], cost savings can reach more than 10 times the initial investment value by using the concept of sustainable design. Energy simulation tools are increasingly used for building energy performance analysis such as Ecotect, Energy Plus and others [10]. However, most of the specific building element information required for energy simulations can be done by using Building Information Modeling (BIM), thus integration is needed with the design process and BIM technology [11-13]. The integration of BIM in the assessment of energy performance in buildings makes a major contribution to reducing energy consumption and $\mathrm{CO}_{2}$ emissions. This study aims to investigate the energy consumption of a building located in Palembang as compared to the benchmark of Indonesian Standard for educational buildings. The initial energy audit was also conducted to determine the value of Energy consumption intensity (EUI) of the buildings using the SNI 03-6169-2000 guidelines and using ASHARE 90.1 benchmarks. Energy audits were carried out to identify the potential for energy savings in all energy-consuming facilities and equipment. Energy audits were also carried out to determine patterns of energy use and potential energy savings. This paper also develops an energy analysis model with BIM integration to produce accurate predictions of the educational building performance with better scenarios. The models can help improve the design decision-making process. The 3D building model was developed with several energy efficiency design strategies.

\section{Literature Review}

Studies on energy consumption have been emerging.
The efficiency of energy use for educational buildings based on LEED Building Rating Systems and the influence of LEED certification to building energy performance were studied [4]. This study recognized impending issues related to attaining sustainable energy policies. A study by Ouf et al [15] also highlighted the energy use of school buildings based on historical energy consumption for a ten-year period as compared to the benchmark. It was found that the age of school buildings had a significant impact on energy consumption, and that new schools consumed more electricity than old ones. The research of [16] examined the standard for energy performance in high school building design and concluded that energy use can be identified based on building design, services design and occupant behavior.

The energy use characteristics for different types of higher education buildings were presented by [17] and also stated that the buildings used for research had a higher Energy Use Intensity (EUI) rather than the academic offices. A study by [18] highlighted the energy performance of different types of school buildings and found that universities consumed more electricity than elementary schools in Taiwan. Moreover, it was also found that the air-conditioning and lighting strongly influenced the energy consumption of school buildings. The research of [19] performed the energy use analysis for educational buildings specifically in humid areas and assessed the material construction, cooling load and lighting that all had/resulted in significant effects on energy consumption. The energy performance of universities accommodation based on the number of electrical appliances used as well as equipment and machinery was also evaluated by Dzulkefli et al [20].

A study by [21] examined the evaluation of building performance on energy consumption in the school buildings in Ecuador using the Autodesk Revit 2017 software. The research presented the comparisons of various building components that produce optimum energy use. The study by Shoubi et al [22] examined energy performance in several cases/scenarios for building, climate, and environmental conditions as well as HVAC systems by involving various information models and building physical conditions. The study by Kamaruzzaman et al [23] analyzed energy and cost savings by controlling daylight in historical buildings in tropical areas. This study stated that lighting consumption in buildings can be influenced by building use, daytime electricity usage, lighting levels and hours of use. The natural and artificial lighting using the Ecotect software was investigated by Chandra et al [24] and it was concluded that the natural lighting entering the room was influenced by the location and the size of the windows, as well as the direction of the sun's trajectory. The study of Shandilya et al [25] presented the optimization of thermal behavior of residential houses under different climates and proposed a retrofitting strategy by keeping the thermal comfort. A study by Yang 
et al [26] conducted an energy analysis of house buildings and developed data conservation strategies related to the local environment by analyzing several factors such as building orientation, building daylight hours, and natural ventilation conditions. Energy-efficient design is defined as the design of buildings to minimize energy use without limiting the function of the building or the comfort or productivity of its occupants. Designing an energy-efficient building is one aspect of achieving sustainable buildings.

According to SNI-03-6196-2000 [27], Energy Use Intensity (EUI) is the ratio between energy consumption and building area unit which is used as an indicator for energy savings in a building. The value of EUI is explained by the amount of energy consumption $(\mathrm{kW})$ per square meter area $\left(\mathrm{m}^{2}\right)$ per month. Table 1 shows the EUI value standard for educational buildings in Indonesia with its classifications for rooms both with and without air conditioning [28]. The EUI value will determine whether a building is classified as highly efficient, efficient, simply efficient or inefficient. Standard criteria for EUI value can be seen as follows.

Table 1. EUI Standard based on the Educational Building Standards (2006) [28]

\begin{tabular}{|c|c|c|}
\hline Criteria & $\begin{array}{c}\text { EUI } \\
\text { for Room with AC } \\
\left(\mathrm{kWh} / \mathrm{m}^{2} / \mathrm{month}\right)\end{array}$ & $\begin{array}{c}\text { EUI } \\
\text { for Room without AC } \\
\left(\mathrm{kWh} / \mathrm{m}^{2} / \mathrm{month}\right)\end{array}$ \\
\hline Very Efficient & $4.17-7.92$ & $0.84-1.67$ \\
\hline Efficient & $7.92-12.08$ & $1.67-2.50$ \\
\hline $\begin{array}{c}\text { Simply } \\
\text { Efficient }\end{array}$ & $12.08-14.58$ & - \\
\hline $\begin{array}{c}\text { Tends to be } \\
\text { inefficient }\end{array}$ & $14.58-19.17$ & - \\
\hline Not efficient & $19.17-23.75$ & $2.50-3.34$ \\
\hline Very Inefficient & -37.50 & -4.17 \\
\hline
\end{tabular}

\section{Research Methodology}

The research was conducted in Palembang by utilizing a two-story educational building. This research used a field survey and measurement method as well as quantitative analysis by comparing the existing measurements to the Indonesian standards for educational buildings. A field survey was performed to investigate the energy consumption in buildings which include the numbers of electrical equipment, equipment operational process mechanisms, hours of use of electrical equipment and the technology used. Since the buildings were built in 1957 , the as-built drawings are no longer available. Therefore, direct measurement of the buildings was conducted to determine floor area and the total area of the building. Based on an interview with the manager of the buildings, the hours of operation can be determined. Meanwhile the number of $\mathrm{AC}$ points, light points and other electronic loads can be determined from direct observation.

The EUI value can be determined by using the equation as follows:

$$
E U I=\frac{P k}{A}
$$

Which:

$$
\begin{aligned}
& \mathrm{EUI}=\text { Energy Use Intensity }\left(\mathrm{kWh} / \mathrm{m}^{2} / \text { month }\right) \\
& \mathrm{Pk}=\text { Total Energy Consumptions }(\mathrm{kWh} / \text { month }) \\
& \mathrm{A}=\text { Total area }\left(\mathrm{m}^{2}\right)
\end{aligned}
$$

The energy consumption of the existing building was determined based on the formula given in equation (1). In addition, 3D building modeling was also performed with BIM Revit software, weather data and building data based on specifications and materials to be simulated in the BIM Revit 2020. The building energy analysis was carried out with the Green Building Studio (GBS) and then the scenario development was conducted using Insight 360 using the DOE 2.2 and Energy Plus simulation engine. The simulation modeling can produce multiple outputs. The maximum EUI value was obtained and then compared with the applicable ASHRAE and SNI standards. Table 2 presented the material characteristics based on the existing data and Table 3 displayed the material characteristics after retrofitting was conducted.

Table 2. Material characteristics of the Existing Building

\begin{tabular}{|c|c|c|c|c|}
\hline $\begin{array}{c}\text { Building } \\
\text { Material }\end{array}$ & Types & $\begin{array}{c}\text { Thickness } \\
(\mathrm{mm})\end{array}$ & $\begin{array}{c}\text { Heat transfer coefficient } \\
(\mathrm{U})(\mathrm{W} / \mathrm{m} 2 . \mathrm{K})\end{array}$ & $\begin{array}{c}\text { Solar Heat } \\
\text { Gain } \\
\text { Coefficient }\end{array}$ \\
\hline Roof & Multiroof/zink & 375 & 5728.57 & - \\
\hline Wall & Light brick & 150 & 5.5102 & - \\
\hline Floor & Ceramics & 210 & 4.8382 & - \\
\hline Ceiling & 2' x 4' ACT System & 57.2 & 3.5906 & - \\
\hline Window glass & $\begin{array}{c}\text { 1/2 in Pilkington } \\
\text { single glazing }\end{array}$ & 5 & 6.2426 & 0.81 \\
\hline
\end{tabular}


Table 3. Material characteristics After Retrofitting

\begin{tabular}{|c|c|c|c|c|}
\hline $\begin{array}{c}\text { Building } \\
\text { Material }\end{array}$ & Types & $\begin{array}{c}\text { Thickness } \\
(\mathrm{mm})\end{array}$ & $\begin{array}{c}\text { Heat transfer } \\
\text { coefficient } \\
(\mathrm{U})\left(\mathrm{W} / \mathrm{m}^{2} . \mathrm{K}\right)\end{array}$ & $\begin{array}{c}\text { Solar Heat } \\
\text { Gain Coefficient }\end{array}$ \\
\hline Roof & Multiroof/zink & 375 & 5728.57 & - \\
\hline Wall & Light brick & 150 & 5.5102 & - \\
\hline Floor & Ceramics Floor & 210 & 4.8382 & - \\
\hline Ceiling & 2'x 4' ACT System & 57.2 & 3.5906 & 0.13 \\
\hline Window glass & $\begin{array}{c}\text { Large double-glazed windows } \\
\text { (reflective coating) }\end{array}$ & 60 & 2.914 & - \\
\hline
\end{tabular}

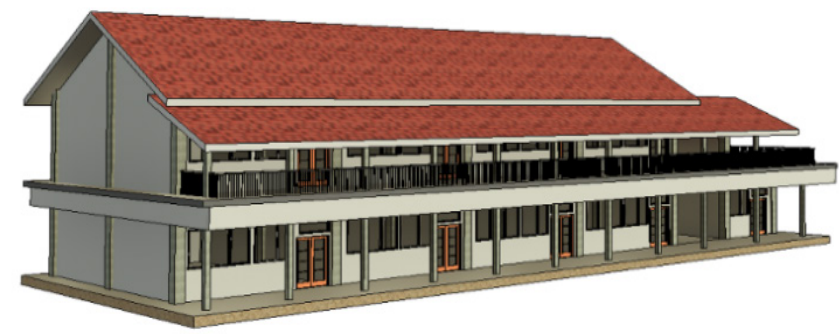

(a)

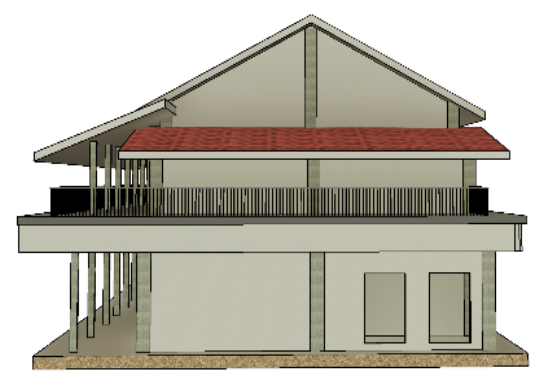

(b)

Figure 1. 3D Perspective (a) from North, (b) from West

Table 4. Total Area of computer lab $\left(\mathrm{m}^{2}\right)$

\begin{tabular}{|c|c|c|c|}
\hline Location & $\begin{array}{c}\text { Air-conditioned room area } \\
\left(\mathrm{m}^{2}\right)\end{array}$ & $\begin{array}{c}\text { Non-AC Room Area } \\
\left(\mathrm{m}^{2}\right)\end{array}$ & $\begin{array}{c}\text { Total Floor Area } \\
\left(\mathrm{m}^{2}\right)\end{array}$ \\
\hline 1st floor & 285.20 & 120.15 & 405.35 \\
\hline 2nd Floor & 261.20 & 96.96 & 358.16 \\
\hline Total & 546.40 & 217.12 & 763.52 \\
\hline
\end{tabular}

In order to overview the energy consumption under different scenarios, several scenarios were developed by modifying some variables such as using renovation designs and other scenario combinations. All scenarios were performed to determine the best model with maximum energy efficiency.

\section{Results and Discussion}

This study was conducted at the SMKN 2 Palembang, a vocational high school located in Palembang City, Indonesia. The school was founded in 1957 and has an area of $4.53 \mathrm{Ha}$, consisting of eleven different engineering majors. Each department has a building that is used as a workshop/laboratory. The computer engineering program is one of the departments in the school of SMKN 2 Palembang and has the biggest computer laboratory compared to the other departments. The energy audit was performed at the computer laboratory building to determine the Energy Use Intensity (EUI) and then compared the results with the EUI benchmark of Indonesian Standard for educational buildings.
The reason to conduct the energy audit in this building is because the computer lab produced the highest energy consumption compared to the other buildings. This building is mostly used for students' purposes and is commonly used for the civil servants entrance examination program in the South Sumatra Province. Figure 1 also shows 3D building perspectives viewed from the North and West side.

The analysis was performed by calculating the EUI value of rooms with air conditioning (AC). Before calculating the EUI, it is necessary to calculate the areas of the building both served by AC and not served by AC on each floor. This building consists of two floors with a total building area about 750.59 square meters as seen in Table 4 . The first floor has a total area $405.35 \mathrm{~m}^{2}$ and the second floor has $358.16 \mathrm{~m}^{2}$. The total area for rooms with air conditioning is $546.40 \mathrm{~m}^{2}$, while those not served by AC are $217.12 \mathrm{~m}^{2}$.

The EUI was estimated for each floor by collecting data on the electrical equipment installed in the room along with the installed power capacity in Watt-hours. Based on the observation and measurement, the load types for each floor 
were divided into 3 types: 1) lighting 2) heating, ventilation, total energy consumed. The total energy consumed was and air-conditioning (HVAC), and 3) electrical equipment calculated by multiplying the number of units used for each (appliances). Table 5 and Table 6 presented the load types item of electrical equipment, power used and duration of for each floor along with value of total power produced or energy consumption.

Table 5. Load Types for First Floor

\begin{tabular}{|c|c|c|c|c|c|c|c|}
\hline \multicolumn{2}{|c|}{ Load Type } & Description & $\begin{array}{c}\text { Unit } \\
\text { Number }\end{array}$ & $\begin{array}{l}\text { Power } \\
\text { (Watt) }\end{array}$ & $\begin{array}{c}\text { Duration of Use } \\
\text { (Hours) }\end{array}$ & $\begin{array}{c}\text { Total Energy } \\
\text { (Watt) }\end{array}$ & Room Type \\
\hline \multicolumn{2}{|r|}{ (1) } & (2) & (3) & (4) & (5) & $(6=3 \times 4 \times 5)$ & \\
\hline \multirow{8}{*}{1} & \multirow{8}{*}{ Lighting } & LED light & 4 & 40 & 9 & 1,440 & Lab. 1 \\
\hline & & LED light & 4 & 40 & 9 & 1,440 & Lab. 2 \\
\hline & & LED light & 4 & 40 & 9 & 1,440 & Lab. 3 \\
\hline & & LED light & 5 & 40 & 9 & 1,800 & Teacher room \\
\hline & & LED light & 1 & 40 & 9 & 360 & $\begin{array}{c}\text { Counseling } \\
\text { room }\end{array}$ \\
\hline & & LED light & 2 & 40 & 9 & 720 & WC \\
\hline & & LED light & 8 & 40 & 9 & 2,880 & Terrace \\
\hline & & & & & Total $=$ & 10,080 & \\
\hline \multirow{11}{*}{2} & \multirow{11}{*}{ HVAC } & $\mathrm{AC}(2 \mathrm{PK})$ & 2 & 1,920 & 9 & 34,560 & Lab. 1 \\
\hline & & Fan & 5 & 85 & 9 & 3,825 & Lab. 1 \\
\hline & & $\mathrm{AC}(2 \mathrm{PK})$ & 2 & 1,920 & 9 & 34,560 & Lab. 2 \\
\hline & & Fan & 5 & 85 & 9 & 3,825 & Lab. 2 \\
\hline & & $\mathrm{AC}(2 \mathrm{PK})$ & 2 & 1,920 & 9 & 34,560 & Lab. 3 \\
\hline & & Fan & 5 & 85 & 9 & 3,825 & Lab. 3 \\
\hline & & $\mathrm{AC}(2 \mathrm{PK})$ & 2 & 1,920 & 9 & 34,560 & Teacher room \\
\hline & & Fan & 2 & 85 & 9 & 1,530 & Teacher room \\
\hline & & $\mathrm{AC}(2 \mathrm{PK})$ & 1 & 1,920 & 9 & 17,280 & $\begin{array}{c}\text { Counseling } \\
\text { room }\end{array}$ \\
\hline & & Fan & 1 & 85 & 9 & 765 & $\begin{array}{c}\text { Counseling } \\
\text { room }\end{array}$ \\
\hline & & & & & Total $=$ & 169,290 & \\
\hline \multirow{19}{*}{3} & \multirow{19}{*}{$\begin{array}{l}\text { Electronic } \\
\text { Equipment }\end{array}$} & Computer & 2 & 450 & 9 & 8,100 & Lab. 1 \\
\hline & & Laptop & 17 & 60 & 9 & 9,180 & Lab. 1 \\
\hline & & Projector & 1 & 100 & 5 & 500 & Lab. 1 \\
\hline & & Printer & 1 & 50 & 5 & 250 & Lab. 1 \\
\hline & & Computer & 2 & 450 & 9 & 8,100 & Lab. 2 \\
\hline & & Laptop & 17 & 60 & 9 & 9,180 & Lab. 2 \\
\hline & & Projector & 1 & 100 & 5 & 500 & Lab. 2 \\
\hline & & Printer & 1 & 50 & 5 & 250 & Lab. 2 \\
\hline & & Computer & 2 & 450 & 9 & 8,100 & Lab. 3 \\
\hline & & Laptop & 17 & 60 & 9 & 9,180 & Lab. 3 \\
\hline & & Infocus & 1 & 100 & 5 & 500 & Lab. 3 \\
\hline & & Printer & 1 & 50 & 5 & 250 & Lab. 3 \\
\hline & & Computer & 1 & 450 & 9 & 4,050 & Teacher room \\
\hline & & Laptop & 11 & 60 & 5 & 3,300 & Teacher room \\
\hline & & Projector & 1 & 100 & 5 & 500 & Teacher room \\
\hline & & Printer & 1 & 50 & 5 & 250 & Teacher room \\
\hline & & Computer & 1 & 450 & 9 & 4,050 & $\begin{array}{c}\text { Counseling } \\
\text { room }\end{array}$ \\
\hline & & Laptop & 1 & 50 & 5 & 250 & $\begin{array}{c}\text { Counseling } \\
\text { room }\end{array}$ \\
\hline & & & & & Total $=$ & 66,490 & \\
\hline & & Tota & & & & 245,860 & \\
\hline
\end{tabular}


Table 6. Load Types for Second Floor

\begin{tabular}{|c|c|c|c|c|c|c|c|}
\hline \multicolumn{2}{|r|}{ Load Type } & Description & $\begin{array}{c}\text { Unit } \\
\text { Number }\end{array}$ & $\begin{array}{l}\text { Power } \\
\text { (Watt) }\end{array}$ & $\begin{array}{l}\text { Duration of } \\
\text { Use (Hours) }\end{array}$ & $\begin{array}{c}\text { Total Energy } \\
\text { (Watt) }\end{array}$ & Room Type \\
\hline \multicolumn{2}{|r|}{ (1) } & (2) & (3) & (4) & (5) & $(6=3 \times 4 \times 5)$ & \\
\hline \multirow{6}{*}{1} & \multirow{6}{*}{ Lighting } & LED light & 6 & 60 & 9 & 3,240 & Lab. 4 \\
\hline & & LED light & 6 & 60 & 9 & 3,240 & Lab. 5 \\
\hline & & LED light & 6 & 60 & 9 & 3,240 & Lab. 6 \\
\hline & & LED light & 6 & 60 & 9 & 3,240 & Teacher room \\
\hline & & LED light & 8 & 40 & 9 & 2,880 & Terrace \\
\hline & & & & & Total $=$ & 15,840 & \\
\hline \multirow{6}{*}{2} & \multirow{6}{*}{ HVAC } & $\mathrm{AC}(2 \mathrm{PK})$ & 2 & 1,920 & 9 & 34,560 & Lab. 4 \\
\hline & & $\mathrm{AC}(2 \mathrm{PK})$ & 2 & 1,920 & 9 & 34,560 & Lab. 5 \\
\hline & & $\mathrm{AC}(2 \mathrm{PK})$ & 2 & 1,920 & 9 & 34,560 & Lab. 6 \\
\hline & & $\mathrm{AC}(2 \mathrm{PK})$ & 2 & 1,920 & 9 & 34,560 & Teacher room \\
\hline & & Fan & 1 & 85 & 9 & 765 & Teacher room \\
\hline & & & & & Total $=$ & 139,005 & \\
\hline \multirow{14}{*}{3} & \multirow{14}{*}{$\begin{array}{l}\text { Electronic Equipment } \\
\text { (appliance) }\end{array}$} & Computer & 23 & 450 & 9 & 93,150 & Lab. 4 \\
\hline & & Projector & 1 & 100 & 5 & 500 & Lab. 4 \\
\hline & & Printer & 1 & 50 & 5 & 250 & Lab. 4 \\
\hline & & Computer & 23 & 450 & 9 & 93,150 & Lab. 5 \\
\hline & & Projector & 1 & 100 & 5 & 500 & Lab. 5 \\
\hline & & Printer & 1 & 50 & 5 & 250 & Lab. 5 \\
\hline & & Computer & 23 & 450 & 9 & 93,150 & Lab. 6 \\
\hline & & Projector & 1 & 100 & 5 & 500 & Lab. 6 \\
\hline & & Printer & 1 & 50 & 5 & 250 & Lab. 6 \\
\hline & & Computer & 4 & 450 & 9 & 16,200 & Teacher room \\
\hline & & Projector & 1 & 100 & 5 & 500 & Teacher room \\
\hline & & Printer & 1 & 50 & 5 & 250 & Teacher room \\
\hline & & Laptop & 13 & 60 & 5 & 3,900 & Teacher room \\
\hline & & & & & Total $=$ & 302,550 & \\
\hline & & Total ( & & & & 457,395 & \\
\hline
\end{tabular}

The LED lights were commonly used for lighting since LED was considered to be more economical and efficient than incandescent light bulbs. In addition, AC using 2 PK (1 PK horse power $=9,000 \mathrm{BTU}$ ) and fans are the types of electronic devices for HVAC used in this building. Other electronic equipment in the laboratory comprised of personal computers, laptops, in-focus, projectors, and printers. The total energy consumption for the first floor consists of lighting (10,080 watts), HVAC (169,290 watts)), and electronic equipment (66,490 watts). Meanwhile for the second floor, lighting (15,840 watts), $\operatorname{HVAC}(139,005$ watts), and electronic equipment (302,550 watts). The average computer usage in a day was approximately 9 hours from Monday to Saturday and the number of effective days in a month was 26 days. The total energy consumed per day for the first floor was around 245,860 watts and 457,395 watts for the second floor. Since the operation days per month were just 26 days, the total consumptions were $6,393,360$ watts per month or 6,392 $\mathrm{kWh} /$ month. The energy consumptions for the second floor were $11,892,270$ watts per month or $118,892 \mathrm{kWh} /$ month.

The distribution of the loads for each floor can be seen in Figure 2. HVAC dominated for about $69 \%$ of the total energy consumption for the first floor, whereas electronic appliances contributed the highest proportion for about $66 \%$. 


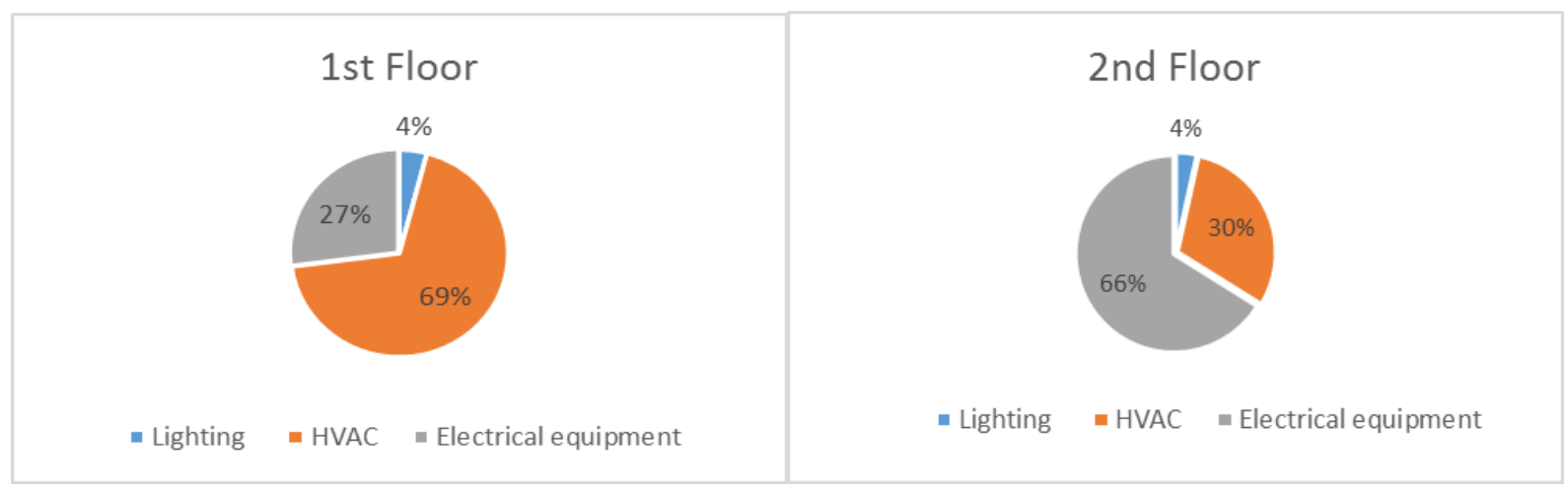

Figure 2. Distribution of load types for the first and second floor

Table 7. EUI Average air-conditioned room

\begin{tabular}{|c|c|c|c|c|c|c|c|c|}
\hline \multirow[t]{2}{*}{ Location } & \multirow{2}{*}{$\begin{array}{c}\text { Total } \\
\text { area }\left(\mathrm{m}^{2}\right)\end{array}$} & \multirow{2}{*}{$\begin{array}{c}\text { Air-conditi } \\
\text { oned area } \\
\left(\mathrm{m}^{2}\right)\end{array}$} & \multicolumn{3}{|c|}{ Energy Consumption (Watt/day) } & \multirow{2}{*}{$\begin{array}{c}\text { Total Energy } \\
\text { (Watt } \\
\text { Per day) }\end{array}$} & \multirow{2}{*}{$\begin{array}{l}\text { Total Energy } \\
\text { (kWh/ month) }\end{array}$} & \multirow{2}{*}{$\begin{array}{c}\text { EUI } \\
\left(\mathrm{kWh} / \mathrm{m}^{2} / \text { month }\right)\end{array}$} \\
\hline & & & Lighting & HVAC & $\begin{array}{l}\text { Electronic } \\
\text { Equipment }\end{array}$ & & & \\
\hline 1st floor & 405.35 & 285.20 & 10,080 & 169,290 & 66,490 & 245,860 & 6,392 & 22.43 \\
\hline $\begin{array}{l}\text { Second } \\
\text { Floor } \\
\end{array}$ & 358.16 & 261.20 & 15,840 & 139,005 & 302,550 & 457,395 & 11,892 & 45.56 \\
\hline Total & 763.52 & 546.40 & 19,440 & 308,295 & 369,040 & \multicolumn{2}{|c|}{ Average $=$} & 33.99 \\
\hline
\end{tabular}

In order to determine the EUI value for each floor, the total energy consumption per month was divided into the total area in square meters which represented the room with $\mathrm{AC}$ only. It was found that the EUI for the first floor was $22.43 \mathrm{kWh} / \mathrm{m}^{2} /$ month, while the second floor was about $45.56 \mathrm{kWh} / \mathrm{m}^{2} /$ month. Based on the EUI values for each floor, the average EUI can be calculated as the summation of EUI divided by 2. Therefore, the average EUI was 33.99 $\mathrm{kWh} / \mathrm{m}^{2} /$ month as seen in Table 7 .

$$
\begin{aligned}
& E U I(1)=\frac{P k}{A}=\frac{6393}{285.20}=22.43 \mathrm{kWh} / \mathrm{m}^{2} / \text { month } \\
& E U I(2)=\frac{P k}{A}=\frac{11,892}{261.20}=45.56 \mathrm{kWh} / \mathrm{m}^{2} / \mathrm{month}
\end{aligned}
$$

By comparing the average value of EUI (33.99 $\left.\mathrm{kWh} / \mathrm{m}^{2} / \mathrm{month}\right)$ to the national standard for building guidelines, the computer laboratory can be classified as a very inefficient building in terms of energy consumption. The category of very inefficient building is/lie within the range of $23.75-37.50 \mathrm{kWh} / \mathrm{m}^{2} /$ month of energy consumption.

In this study, EUI calculations were carried out in two ways. First, the electrical data used in the building was calculated and then compared with the SNI 03-6196-2000 standard. Secondly, a 3D model was developed by redrawing the building object using the BIM Revit application which follows the ASHRAE 90.1 benchmark standards. Revit Insight 360 was used to simulate the data and calculate the electrical energy consumption using the SNI 03-6169-2000 guidelines and using ASHARE 90.1 benchmarks.

The renovation designs were suggested to improve the energy performance by developing different scenarios. Figure 3 presented the view of the building before and after the renovation designs suggested. In this paper, 9 scenarios were developed as presented in Figure 4 and Table 8. The renovation designs were made by changing the facade of the building, beginning with changing the shape of the roof, making windows wider and higher, and adding continuous columns from bottom to top to support the roof. The result indicates that the EUI value is around $248 \mathrm{kWh} / \mathrm{m}^{2} /$ year, $61.06 \mathrm{kWh} / \mathrm{m}^{2} /$ year for total energy savings and $9.76 \%$ for energy efficiency. 


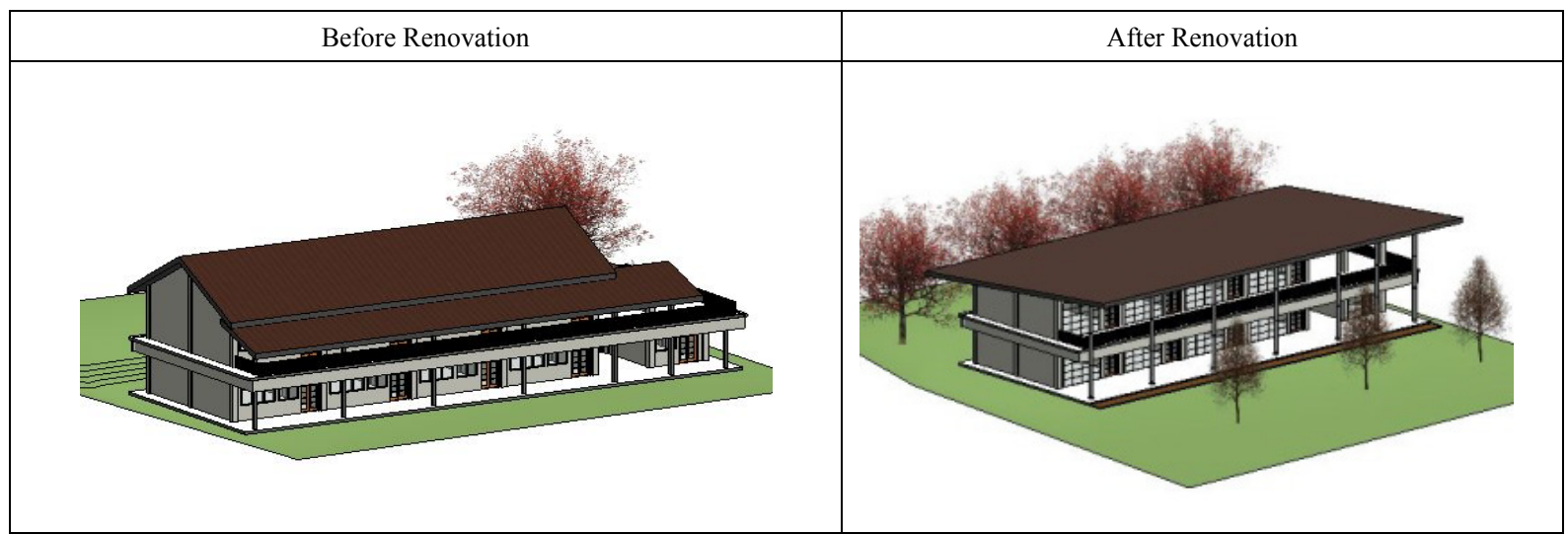

Figure 3. Building views before and after renovation design
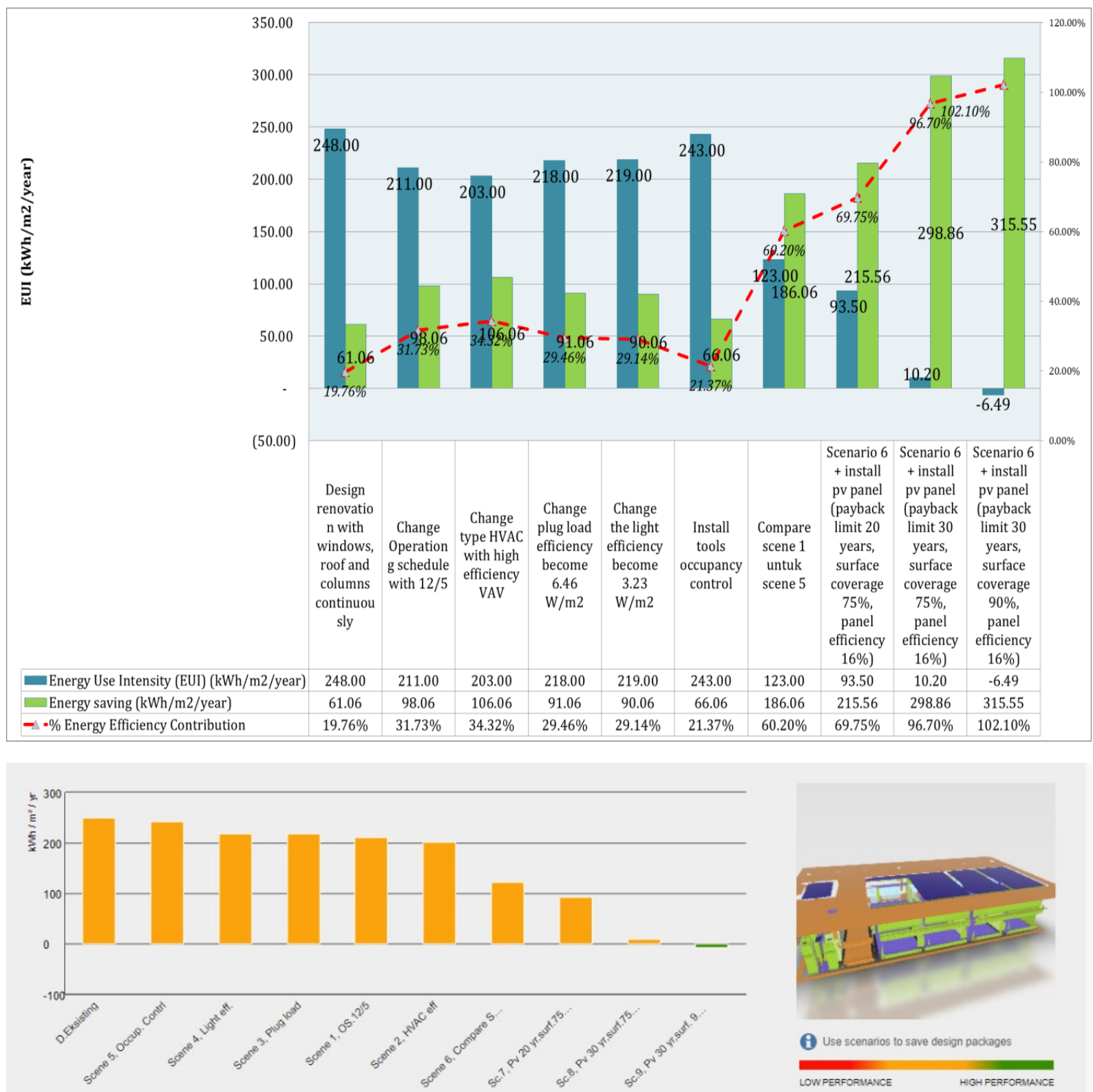

Figure 4. Energy Consumption and Energy Savings based on different scenarios 
Based on the renovation designs, 9 scenarios were developed to measure the amount of potential energy savings generated by the building using the Insight 360 web-based energy analysis tool. Scenario 1 was developed by changing the operating schedule from $12 / 6$ to $12 / 5$, indicating 12 hours in 5 days. Scenario 1 resulted in an EUI value of $211.00 \mathrm{kWh} / \mathrm{m}^{2} /$ year with an energy efficiency of $31.73 \%$. The second scenario was to change the cooling system that previously used Split AC to a VAV central AC type with high efficiency for educational buildings, resulting in an EUI value of $203.00 \mathrm{kWh} / \mathrm{m}^{2} /$ year and $34.23 \%$ for energy efficiency. The third scenario was that the building served with electrical equipment with a high efficiency up to $6.46 \mathrm{~W} / \mathrm{m}^{2}$, resulting in an EUI value of $218.00 \mathrm{kWh} / \mathrm{m}^{2} /$ year and $29.46 \%$ of energy efficiency.

In the fourth scenario, the building was served with special energy-efficient lighting equipment and had a high efficiency up to $3.23 \mathrm{~W} / \mathrm{m}^{2}$, resulting in an EUI of 219.00
$\mathrm{kWh} / \mathrm{m}^{2} /$ year with a total energy efficiency of $29.14 \%$. In the fifth scenario, the building was installed with light sensors from outside and occupancy control resulting in an EUI value of $243.00 \mathrm{kWh} / \mathrm{m}^{2} /$ year and an energy efficiency of $21.37 \%$. The sixth scenario was a combination of scenarios 1 through scenario 5, which had an EUI value of $123.00 \mathrm{kWh} / \mathrm{m}^{2} /$ year with an energy efficiency of $60.20 \%$. The seventh scenario was that the building was installed with solar panels with a time limit of 20 years, and $75 \%$ of surface coverage resulting in the EUI value of 93.50 $\mathrm{kWh} / \mathrm{m}^{2} /$ year and an energy efficiency of $69.75 \%$. In the eighth scenario, the building was installed with solar panels with a time limit of 30 years and a surface coverage of $75 \%$, producing an EUI value of $10.20 \mathrm{kWh} / \mathrm{m}^{2} /$ year and an energy efficiency of $96.70 \%$. In the last scenario, the building was installed with solar panels with a time limit of 30 years, and $90 \%$ of surface coverage, and the resulting EUI is $-6.49 \mathrm{kWh} / \mathrm{m}^{2} /$ year with an energy efficiency of $102.10 \%$.

Table 8. Energy Use Intensity and Energy Efficiency based on Scenario Development

\begin{tabular}{|c|c|c|c|c|c|c|}
\hline No & $\begin{array}{c}\text { Scenario } \\
\text { Development }\end{array}$ & Variables & $\begin{array}{l}\text { Existing } \\
\text { variables }\end{array}$ & $\begin{array}{c}\text { Energy Use } \\
\text { Intensity (EUI) } \\
\left(\mathrm{kWh} / \mathrm{m}^{2} / \text { year }\right) \\
\end{array}$ & $\begin{array}{l}\text { Energy saving } \\
\left(\mathrm{kWh} / \mathrm{m}^{2} / \text { year }\right)\end{array}$ & $\begin{array}{c}\text { Energy } \\
\text { Efficiency } \\
(\%) \\
\end{array}$ \\
\hline 1 & $\begin{array}{l}\text { Existing } \\
\text { building }\end{array}$ & Design before renovation & $\begin{array}{l}\text { Existing } \\
\text { building }\end{array}$ & 309 & 0.00 & $0 \%$ \\
\hline 2 & $\begin{array}{l}\text { Renovation } \\
\text { design }\end{array}$ & $\begin{array}{l}\text { Design renovation with windows, } \\
\text { roof and columns continuously }\end{array}$ & - & 248 & 61.06 & $19.76 \%$ \\
\hline 3 & Scenario 1 & $\begin{array}{l}\text { Change Operation schedule with } \\
12 / 5\end{array}$ & $\begin{array}{c}\text { Operation } \\
12 / 6\end{array}$ & 211 & 98.06 & $31.73 \%$ \\
\hline 4 & Scenario 2 & $\begin{array}{c}\text { Change type HVAC with high } \\
\text { efficiency VAV }\end{array}$ & AC Split & 203 & 106.06 & $34.32 \%$ \\
\hline 5 & Scenario 3 & $\begin{array}{c}\text { Change plug load efficiency } \\
\text { become } 6.46 \mathrm{~W} / \mathrm{m}^{2}\end{array}$ & $13.99 \mathrm{~W} / \mathrm{m}^{2}$ & 218 & 91.06 & $29.46 \%$ \\
\hline 6 & Scenario 4 & $\begin{array}{c}\text { Change the light efficiency } \\
\text { become } 3.23 \mathrm{~W} / \mathrm{m}^{2}\end{array}$ & $11.84 \mathrm{~W} / \mathrm{m}^{2}$ & 219 & 90.06 & $29.14 \%$ \\
\hline 7 & Scenario 5 & $\begin{array}{l}\text { Install tools daylight and } \\
\text { occupancy control }\end{array}$ & $\begin{array}{c}\text { No } \\
\text { installation }\end{array}$ & 243 & 66.06 & $21.37 \%$ \\
\hline 8 & Scenario 6 & Combination scene 1 until scene 5 & - & 123 & 186.06 & $60.20 \%$ \\
\hline 9 & Scenario 7 & $\begin{array}{c}\text { Combination Scenario } 6+\text { install } \\
\text { pv panel (payback limit } 20 \text { years, } \\
\text { surface coverage } 75 \% \text {, panel } \\
\text { efficiency } 16 \% \text { ) }\end{array}$ & - & 93.5 & 215.56 & $69.75 \%$ \\
\hline 10 & Scenario 8 & $\begin{array}{c}\text { Combination Scenario } 6+\text { install } \\
\text { pv panel (payback limit } 30 \text { years, } \\
\text { surface coverage } 75 \% \text {, panel } \\
\text { efficiency } 16 \% \text { ) }\end{array}$ & - & 10.2 & 298.86 & $96.70 \%$ \\
\hline 11 & Scenario 9 & $\begin{array}{c}\text { Combination Scenario } 6+\text { install } \\
\text { pv panel (payback limit } 30 \text { years, } \\
\text { surface coverage } 90 \% \text {, panel } \\
\text { efficiency } 16 \% \text { ) }\end{array}$ & - & -6.49 & 315.55 & $102.10 \%$ \\
\hline
\end{tabular}


An EUI value of $-6.49 \mathrm{kWh} / \mathrm{m}^{2} /$ year indicated that there was almost no energy consumed. This building scenario could provide energy export and save the energy excess. This may be caused by the decrease in building energy and the installation of photovoltaic panel devices that can produce energy. The building based on this scenario was classified as an energy efficient building with high performance and can save energy, if needed, at any time. Thus, it can be concluded that the ninth scenario produced the best scenario with the least amount of energy consumption. This also implies that the EUI values based on the simulation were much lower than the existing EUI calculated based on the equation 1. It can also be concluded that there was a significant improvement on the energy use reduction and a substantial increase for energy savings under different renovation design scenarios. The renovation designs could significantly improve potential energy savings. Insight 360 results can be used as a temporary reference for preliminary design because they allow the analysis of building models quickly and accurately. However, the drawback is that not all design factors can be used in Indonesia because there are variables such as wall/roof seal that are not the same as those provided in Insight 360. Finally, the results will help decision makers identify the potential for energy savings in all energy-consuming facilities and equipment in the building as well as develop strategies to save energy.

\section{Conclusions}

This study aims to investigate the energy consumption of an existing educational building located in Palembang as compared to the benchmark of Indonesian Standard for educational buildings. The research was conducted in Palembang by utilizing a two-story educational building to determine the value of Energy Use Intensity (EUI) and then to compare the results to the benchmark. It was found that HVAC dominated for about $69 \%$ of total energy consumption for the first floor, whereas electronic appliances contributed the highest proportion for about $66 \%$ for the second floor. The EUI value for the first floor was $22.43 \mathrm{kWh} / \mathrm{m}^{2} /$ month, while the second floor was about $45.56 \mathrm{kWh} / \mathrm{m}^{2} /$ month, resulting in an average EUI around $33.99 \mathrm{kWh} / \mathrm{m}^{2} / \mathrm{month}$. The building was then classified as a very inefficient building in terms of energy consumption. The renovation designs were then suggested to improve the energy performance by developing 9 different scenarios.

The last scenario in which the building installed with solar panels with a time limit of 30 years and $90 \%$ of surface coverage produced the EUI value -6.49 $\mathrm{kWh} / \mathrm{m}^{2} /$ year with an energy efficiency of $102.10 \%$. This building scenario could provide energy export and save energy excess. This was influenced by the decrease in building energy and the installation of photovoltaic panel devices that can produce energy. The building based on this scenario was classified as an energy efficient building with high performance and able to save energy if needed at any time. Thus, it can be concluded that the ninth scenario produced the best scenario with the least energy consumption. This also implies that EUI values based on the simulation were much lower than the existing EUI calculated based on equation 1 . Thus, it can be concluded there was a significant improvement in energy use reduction and a substantial increase for energy savings under renovation design scenarios. The renovation designs could significantly improve potential energy savings. Insight 360 results can be used as a temporary reference for preliminary design because it allows the analysis of building models quickly and accurately. However, the drawback is that not all design factors can be used in Indonesia because there are variables such as wall/roof seal that are not the same as those provided in Insight 360. Finally, the results will help the decision makers identify the potential for energy savings in all energy-consuming facilities and equipment in the building as well as develop strategies for energy conservation.

\section{Acknowledgments}

The research of this article was funded by DIPA of Public Service Agency of Universitas Sriwijaya 2020. SP DIPA-023.17.2.67715/2020, revision 01, on March 16, 2020. In accordance with the Rector's Decree Number: 0685/UN9/SK.BUK.KP/2020, on July 15, 2020. And thank you for Dr. Marc Lucht's brilliant and wonderful language editing.

\section{REFERENCES}

[1] Pulselli RM, Simoncini E, and Pulselli FM, Bastianoni S, "Energy analysis of building manufacturing, maintenance and use: building indices to evaluate," Energy and Buildings, 39 (5): 620-8, 2007.

[2] Provincial Government of DKI Jakarta, "Building Coverings, User Manual for Green Buildings in Jakarta,” vol. 1, 2012.

[3] Moakher, PE \& Pimplikar, SS, "Building Information Modeling (BIM) and Sustainability - Using Design Technology in Energy Efficient Modeling," Journal of Mechanical and Civil Engineering, 1 (2), pp. 10-21, 2012.

[4] Jrade A and Jalaei F, "Integrating building information modeling with sustainability to design building projects at the conceptual stage," Build. Simul. 6 (4) 429-44, 2013.

[5] Mao, J., Pan, Y. \& Fu, Y, "Towards fast energy performance evaluation: A pilot study for office buildings," Energy and Buildings, vol. 121, pp. 104-113, 2016.

[6] Bergin, M., Rahmani A. M., Menter, A. \& Yan, W, "Autodesk Research - BIMbased Parametric Building Energy Performance Multi Objective Optimization,” 2014. 
[Online] Available at: https://autodeskresearch.com/publicat ions/bimparametric

[7] Solla, M., Ismail, L., Yunus, R, "Investigation on the potential of integrating BIM into green building assessment tools," ARPN J. Eng. Appl. Sci. 11, 2412-2418, 2016.

[8] Fitriani, I, "Evaluation of Electrical Energy Efficiency in Dr. Sayidiman of Magetan Regency," Master Thesis of Civil Engineering Study Program, Sebelas Maret University, Surakarta, 2017.

[9] Azhar, S., Carlton, WA, Olsen, D. \& Ahmad, I, "Building information modeling for sustainable design and LEED ${ }^{\circledR}$ rating analysis," Automation in Construction, 20 (2), pp. 217-224, 2011

[10] Aksamija, A. \& (Perkins+Will), T. L. American Council for an Energy-Efficient Economy - BIM-Based Building Performance Analysis: Evaluation and Simulation of Design Decisions, 2012. [Online] Available at: http://aceee.org/files /proceedings/2012/data/papers/0193-000367.pdf

[11] Fitriani, H., Budiarto, A., Ajayi, S., dan Idris, Y. "Implementing BIM in Architecture, Engineering and Construction Companies: Perceived Benefits and Barriers among Local Contractors in Palembang, Indonesia.". International Journal of Construction Supply Chain Management, 9(1): 20-34, 2019.

[12] Moakher, P. E. \& Pimplikar, S. S. Building Information Modeling (BIM) and Sustainability - Using Design Technology in Energy Efficient Modeling. Journal of Mechanical and Civil Engineering, 1(2), pp. 10-21, 2012.

[13] Oduyemi, O. \& Okoroh, M. International Journal of Sustainable Build Environment. Building performance modelling for sustainable building design, 2016.

[14] Agdas, D., Srinivasan, R. S., Frost, K., \& Masters, F. J, "Energy use assessment of educational buildings: Toward a campus-wide sustainable energy policy," Sustainable Cities and Society, 17, 15-21, 2015. https://doi.org/10.1016/j.scs.2 015.03.001

[15] Ouf, M. M., \& Issa, M. H, "Energy consumption analysis of school buildings in Manitoba, Canada," International Journal of Sustainable Built Environment, 6(2), 359-371, 2017. https://doi.org/10.1016/j.ijsbe.2017.05.003

[16] Salleh, M. N. M., Kandar, M. Z., \& Sakip, S. R. M, "Benchmarking for Energy Efficiency on School Buildings Design: A Review," Procedia - Social and Behavioral Sciences, 222, 211-218, 2016. https://doi.org/10.1016/j.sbsp ro.2016.05.149

[17] Khoshbakht, M., Gou, Z., \& Dupre, K, "Energy use characteristics and benchmarking for higher education buildings," Energy and Buildings, 164 (November), 61-76, 2018. https://doi.org/10.1016/j.enbuild.2018.01.001
[18] Wang, J. C, "A study on the energy performance of school buildings in Taiwan," Energy and Buildings, 133, 810-822, 2016. https://doi.org/10.1016/j.enbuild.2016.10.036

[19] Sait, H. H, "Auditing and analysis of energy consumption of an educational building in hot and humid area," Energy Conversion and Management, 66, 143-152, 2013. https://doi.org/10.1016/j.enconman.2012.10.005

[20] Dzulkefli, M. H, “The energy audit process for universities accommodation in Malaysia: A preliminary study," IOP Conference Series: Earth and Environmental Science, 67(1), 2017. https://doi.org/10.1088/1755-1315/67/1/012027

[21] Flores, MSM, "Building performance evaluation using Autodesk Revit for optimizing the energy consumption of an educational building on subtropical highland climate: A case of study in Quito, Ecuador," Master's Thesis in Renewable Energy and Architecture, University of Nottingham, 2016.

[22] Shoubi, MV, Shoubi, MV, Bagchi, A. \& Barough, "Reducing the operational energy demand in buildings using building information modeling tools and sustainability approaches," Ain Shams Engineering Journal, 6 (1), pp. 41-55, 2015.

[23] Kamaruzzaman, Syahrul Nizam., Edwards, Rodger, "Achieving energy and cost savings through simple daylighting control in tropical historic buildings," Journal of Energy and Buildings, Vol. 90. Pg. 85-93, 2014. https://ukm.pure.elsevier.com/en/publications/achieving-ene rgy-and-costsavings-through-simple-daylighting-cont

[24] Chandra, Tiffany. \& Amen, Abd. R. Zahrial, "Simulation of Natural and Artificial Lighting with Ecotect Radiance in Image Studio," Journal of Composition Architecture, Vol. 10, no 3 pg. 171-181, 2013. http://library.gunadarma.ac.id/journ al/view/13707/simulasi-pencahaya-alamidan-buatan-dengan -ecotect-radiance-pada-studio-gambar.html/

[25] Shandilya, M. Hauer, and W. Streicher, "Optimization of thermal behavior and energy efficiency of a residential house using energy retrofitting in different climates," Civil Engineering and Architecture, vol. 8, no. 3, pp. 335-349, 2020, doi: 10.13189/cea.2020.080318.

[26] Yang, Li., Jie He, Bao. Ye, Miao, "Application research of Ecotect in residential estate Planning," Journal of Energy and Buildings, Vol. 72. Pg. 195-202, 2014 https://ukm.pure.elsevier.com/en/publications/achieving-ene rgy-and-costsavings-through-simple-daylighting-cont.

[27] SNI 03-6196-2000, "Energy Audit Procedures for Buildings, National Standardization Agency for Indonesia," Jakarta, 2000 .

[28]Departemen Pendidikan Nasional Republik Indonesia, "Pedoman Pelaksanaan Konservasi Energi dan Pengawasan Di Lingkungan Departemen Pendidikan Nasional," Jakarta, 2006. 